МІЖНАРОДНЕ ПРАВО

\author{
ALLAHVERDIYEV ALOVSAT \\ VILAYET OGLU, \\ Doctor of Philosophy, Associate Professor, \\ Doctoral Student of the Doctor Sciences \\ Degree \\ (Baku State University)
}

DOI https://doi.org/10.32842/2078-3736/2021.3.21

\title{
THE ROLE OF THE YUGOSLAVIA TRIBUNAL IN PERSECUTION OF WAR CRIMES
}

The purpose and objectives of the study are to highlight war crimes as a serious threat to international peace and security, to fight them at the international level and to explain the importance of prosecution at the level of international criminal tribunals.

Research methods. The research preference was given to comparative analysis and methods of analysis. In particular, the various judgments of the Yugoslav tribunal were mentioned. It is very important to study war crimes and analyze new trends associated with them.

The scientific novelty. It is very important to develop the principle of immunity of officials for international crimes, especially war crimes, and to apply this principle in countries that have become hotbeds of armed conflicts in our time. Today these people continue to abuse their status and commit international crimes.

Conclusion. The article examines the essence of war crimes and methods of combating them. First, the approach of the Charter of the Nuremberg Tribunal to war crimes was explained, and then the issues of the prosecution of war crimes by the Yugoslav Tribunal in our time and the prosecution of military and political leaders were discussed. The author also referred to the judgments of the Yugoslav Tribunal and analyzed them to explain the war crimes. The article analyzes the activities of the Yugoslav Tribunal, created to investigate international crimes in the former Yugoslavia. According to the Tribunal's charter, war crimes were seen as a violation of international humanitarian law and the Geneva Conventions. The Yugoslav Tribunal is the first court to investigate war crimes since the Nuremberg Tribunal. It is known as an institution that has gained considerable prestige through its research. At the time of its creation, many did not believe that he would work on such a large territory and achieve success.

Throughout history, it has been known that wars have brought nothing but fear and suffering to humanity. For this reason, wars are undesirable for all societies. War crimes arising from wars are considered an act against international peace and security. In short, war crimes are acts that violate international humanitarian law and the Geneva Conventions.

The term "war crime" in the broadest sense means that all those who act in violation of international law in connection with armed conflict may be prosecuted and punished. Of course, this does not exclude a direct connection with crimes against peace, crimes against humanity and genocide. In general, "war crimes" are violations of the laws and customs of war. For this reason, in order to get a complete picture of war crimes, it is necessary to show all the elements of this category of crimes.

Key words: war, war crimes, Yugoslav Tribunal, international crimes, persecution, crimes against humanity.

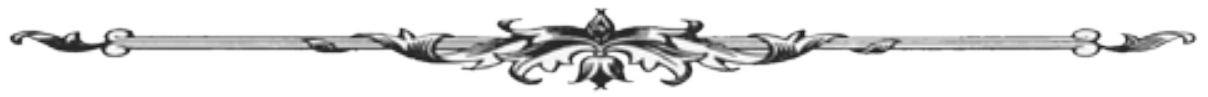




\section{Аллахвердісв Аловсат Вилаят оглу. Роль Югославського Трибуналу в розслідуванні військових злочинів \\ Мета і завдання дослідження - виокремити військові злочини як серйозну загрозу міжнародному миру i безпеці, боротися 3 ними на міжнародному рівні і пояснити важливість судового переслідування на рівні міжнародних кримінальних трибуналів.}

Методи дослідження. Перевагу в дослідженні було віддано порівняльному аналізу і методам аналізу. Зокрема, були згадані різні постанови югославського трибуналу. Дуже важливо вивчати військові злочини і аналізувати нові тенденції, пов' язані з ними.

Наукова новизна дослідження. Дуже важливо розвивати принцип імунітету посадових осіб за міжнародні злочини, особливо військові злочини, і застосовувати цей принцип у країнах, які в наш час стали вогнищами збройних конфліктів. Сьогодні ці люди продовжують зловживати своїм статусом і вчиняти міжнародні злочини.

Висновок. У статті розглядається сутність військових злочинів і методи боротьби 3 ними. Спочатку було роз'яснено підхід Статуту Нюрнберзького трибуналу до військових злочинів, а потім були обговорені питання переслідування військових злочинів Югославським трибуналом у наш час і кримінального переслідування військових і політичних лідерів. Він також послався на постанови Югославської Трибуналу і проаналізував їх для пояснення військових злочинів. У статті аналізується діяльність югославського трибуналу, створеного для розслідування міжнародних злочинів у колишній Югославії. Згідно зі статутом трибуналу військові злочини були розцінені як порушення міжнародного гуманітарного права і Женевських конвенцій. Югославський трибунал-перший суд, який розслідував військові злочини після Нюрнберзького трибуналу. Він відомий як установа, яке набуло значного престиж завдяки своїм дослідженням. На момент його створення багато хто не вірив, що він буде працювати на такій великій території і досягне успіху.

Термін «військовий злочин» означає, що всі особи, які діють у порушення міжнародного права у зв'язку зі збройним конфліктом, можуть бути притягнуті до відповідальності і покарані. Звичайно, це не виключає прямого зв'язку зі злочинами проти миру, проти людяності і геноцидом. Загалом, «військові злочини» - це порушення законів і звичаїв війни. Через це, щоб отримати повне уявлення про військові злочини, необхідно показати всі елементи цієї категорії злочинів.

Ключові слова: війна, військові злочини, Югославський Трибунал, міжнародні злочини, переслідування, злочини проти людяності.

Introduction. Historical processes show that states that are always under pressure or aggression are always looking for justice. Societies that are victims of injustice are often doomed to collapse. One always wonders why leaders fail to prevent crimes such as war crimes, crimes against humanity and genocide, which oppress humanity, and generally hinder or reject the search for international justice in general. As a result, public policy and interests take precedence over the principles of law and justice. Given that law and international politics interact, law has greater power and influence [1, pg-s. 175-176]. Unfortunately, in many cases, it is impossible for them to interact, which is why nations become victims of aggressive interests and policies. The concepts of "war" and "war crimes" are very relevant today. Modern wars and crimes are among the factors that make this urgent. Both not only maintained their relevance after World War II, but also increased its urgency, which rightly caused concern in the international community.

Living in a war is not unequivocal. It is known that any society condemns wars, which can be desired mainly by the imperialists and the citizens of the countries that have been victims of injus-

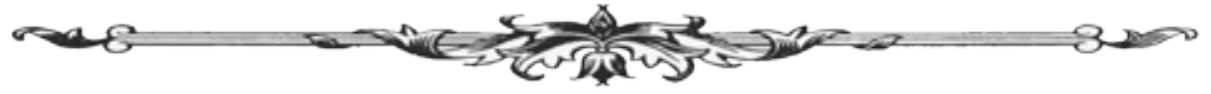


tice and aggression. This can be clearly seen from the experience of states. War crimes and other types of international crimes are inevitable in the area of aggression. According to the Dutch lawyer Hugo Grotius, a prominent representative of the theory of natural law, war is the realization of the desires of a society or a group of states by using force against the unity of other societies and states [2]. He believed that war was completely contrary to the rules of natural law.

The degree to which the subject was studied. The study of the prosecution of war crimes by the Yugoslav Tribunal and the trial of the perpetrators was examined in accordance of the books published in Azerbaijani, Russian and English, scientific research materials, charters, protocols and information from various Internet sources. In his study of 'International Humanitarian Law and Criminal Trials', W.J. Fenrick focused on international humanitarian law and the work of international criminal tribunals. As a result of violation of these norms, he brought to the attention the work of tribunals on specific crimes. At the same time, R.W.D Cohn's book "The Practice of the International Criminal Tribunals for the Formation of Yugoslavia and Rwanda" reflects the investigations of Yugoslav and Rwandan tribunals into war crimes and focuses on the trials of military and political leaders. Moreover, special attitude was paid to the elements of war crimes.

Method. While dedicated to the analysis of war crimes prosecution by the Yugoslav Tribunal this article focuses on comparative analysis and analysis methods. Along with the academic content, the legal documents also were analyzed and quality was given as the priority.

Presentation of the main content. It has been known throughout history that wars bring nothing but fear and misery to mankind. War is not fear or misery for those who deliberately rule it. States that want to secure their interests and enrich their economies are either participants in the war or those who control it. At best, wars around the world have left civilians with incurable wounds. Although a number of international legal measures have been taken to prevent these crimes, the interests of the major powers often underestimate the requirements of international law, especially when impunity for violators of international law is a major blow to trust and confidence in international law. From this point of view, it is very necessary and important to study war crimes and analyze new trends related to them. Earlier, the fight against these crimes was generally regulated by international law, but today the fight against war crimes has been strengthened within the framework of international criminal law, and interstate cooperation in the field of extradition has been expanded. Nevertheless, states interested in wars still remain in their ampoules, and, unfortunately, war remains a method of struggle between forces. This continues to be a source of danger to humanity.

"War crimes" arising from wars are a broad concept and cover many different acts committed during an armed conflict. Consideration of this concept in the context of international law and the diversity of approaches to it do not allow it to be expressed in a single concept. The term "war crime" in the narrow sense refers to the violation of the laws and customs of war. These include: Conventions;

- Serious violations of the Geneva Conventions or the Additional Protocols to the Geneva

- Violation of the Hague Conventions;

- Violation of the laws and customs of war

The term "war crime" in the broadest sense means that all those who act in violation of international law in connection with armed conflict can be prosecuted and punished [3]. Of course, this does not exclude a direct connection with crimes against peace, crimes against humanity and genocide. In general, "war crimes" are violations of the laws and customs of war. For this reason, in order to get a full picture of war crimes, it is necessary to show all the elements of this category of crimes. In general, war crimes are a broad legal category, covering serious violations of international humanitarian law in times of armed conflict, both international and non-international. Each of these violations is in itself a specific criminal act and gives rise to international criminal liability. There are different approaches in the scientific literature to the acceptance of the act as a war crime. For example, I. Lukashuk believes that war crimes are a systematic or a serious violation of the provisions of international humanitarian law during armed conflict [4, pg-s. 423-433].

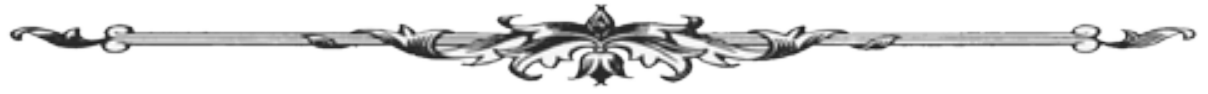


Huseynov L. believes that the concept of "war crime" is, in general, a violation of international humanitarian law and the customs and laws of war during an armed conflict [5, pg-s. 230-231].

It is an undeniable fact that after World War II, there has been significant progress in international law in the fight against war and acts that constitute international crime. Numerous trials of people convicted of war crimes from the fascist bloc countries, the trial of political and military leaders (Nuremberg Principles) confirm this. The Nuremberg Tribunal prosecuted and punished individuals for war crimes, crimes against humanity and genocide.

The Charter of the Nuremberg Tribunal can be considered an important document in modern times in terms of the international legal definition of war crimes. In accordance with Article 6 (b) of the Charter, war crimes include violations of the laws and customs of war. The latter combines the following elements: murder; deportation of the occupied territory or the civilian population in the occupied territories for cruel treatment or exploitation of slave labor or for other purposes; killing or ill-treatment of prisoners of war or persons at sea; killing of hostages; looting of state or private property; meaningless destruction or devastation of cities, settlements or villages without military justification.

The basic rule of international humanitarian law is that civilians enjoy general protection against threats posed by military operations. The rule of civil immunity is one of the "oldest fundamental maxima" of international customary law, i.e. it is binding on the parties to the conflict, regardless of whether the conflict is international or non-international in nature [6, p. 120]. Any party to the conflict is obliged to respect the norms of international law. Attacks on civilians are prohibited, and if one of the parties does so intentionally, it directly constitutes a war crime. Thus, the civilian population and individual civilians cannot be the target of an attack, and the spread of terror or similar threats of violence among the civilian population is prohibited [7]. To ensure respect and protection of civilians and civilian objects, the parties to the conflict must always distinguish between civilians and fighters, between civilian objects and military purposes, and therefore direct their operations only against military forces [8].

Since the Nuremberg Trials, there has been a strong belief in the international community that wars will no longer be encouraged and that war crimes will not occur. Punishment, especially for those responsible for crimes, reinforced this belief, but it did not work. Thus, simply the method changed, to put it mildly, the interests of the states did not allow the content to change, the force was applied not through armed means, but through political, economic and diplomatic pressures. That is, the form has changed, the content has remained the same. At the same time, there were those in the international community who made serious attempts to deny war crimes. For this, cooperation was refused and the criminals were not prosecuted. This, in turn, seriously damaged the work of international criminal justice agencies. Nevertheless, as a continuation of the Nuremberg Trials, tribunals of Yugoslavia and Rwanda were established, which functioned as ad hoc.

On May 25, 1993, the UN Security Council decided to establish the Yugoslav Tribunal as a mechanism for the restoration and protection of international peace and security, taking a truly extraordinary and unprecedented step. In the course of its work, the tribunal has radically changed the landscape of international humanitarian law and given victims the opportunity to voice the horrors they have witnessed. This was an extremely important innovation in the use of coercive executive powers by the Security Council and a manifestation of the clear link between peace and justice-politics and law. This was followed by the establishment of interim courts for the former Yugoslavia and Rwanda, the adoption of the Rome Statute by the International Criminal Court in July 1998, the arrest of General Augusto Pinochet in London in October 1998, and the establishment of interim courts in Cambodia. Sierra Leone and East Timor all point to the emerging norm of international criminal justice. The tribunal was established as a political tool, but the court was not a political tool. Our goal is to systematically investigate the Tribunal, what it is, why it was created, how it works and how important it is. To do this, let's look at the Charter of the Yugoslav Tribunal, which contains war crimes. The Tribunal's Charter contained "serious violations of Article 3 of the Geneva Conventions" (an article of the Geneva Conventions relating to civil

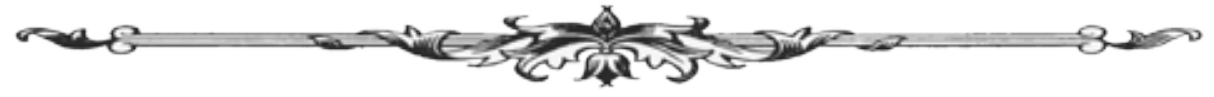


wars), as well as other regulations protecting victims of armed conflict and basic regulations on the methods of warfare [9].

The tribunal's task is to bring to justice those responsible for international humanitarian law violations committed in the former Yugoslavia since 1991. According to Article 1 of the Charter, the Court falls into four categories of "serious violations of international humanitarian law" committed by individuals in the former Yugoslavia since 1991: gross violation of the Geneva Convention (Article 2); violation of laws and customs of war (Article 3); genocide (Article 4) and crimes against humanity (Article 5). International humanitarian law is not an international criminal code; both more and less. The aim is to protect those who fight and those who do not fight from unnecessary suffering and to protect the basic human rights of those who fall into the hands of the enemy. It is perceived as having a protective function, not as a basis for criminal prosecution. The emergence of international treaties and conventions, often thought out in an abstract way, and through the development of traditional international law, means that they contain misunderstandings $[10$, p. 78$]$.

Despite all the criticism, the establishment and operation of the Yugoslav Tribunal can be considered a success of international law. It is clear that no force can undo the terrible traces of the crimes committed in Yugoslavia, the damage done, the losses lost in the war, but the results did not fully restore everything, but the perpetrators were convicted. However, we believe that such criminals should not have been sentenced to 25-30 years in prison, but should have been sentenced to a heavier sentence. To this end, the Court had to be sufficiently supported by international organizations and states. Unfortunately, the positions of states opposed to the prosecution of officials sometimes hampered the speed of the process. The tribunal has been quite successful since its inception in 1993 to investigate genocide and crimes against humanity, including war crimes committed during the 1990's conflict in the Balkans, and has prosecuted specific individuals, especially officials, for these crimes. In its precedent decisions on genocide, war crimes, and crimes against humanity, the Tribunal has shown that a person's high office cannot protect them from persecution. Thus, the Tribunal abused the authority of officials, undermined their ability to exercise their immunity for genocide, war crimes and crimes against humanity, and held each of them accountable. In doing so, he contributed to international law. According to the position of the Yugoslav Tribunal, the essence of the privileges and immunities and immunity of officials must be properly understood. This immunity must be applied in cases permitted by law, and the abuse of immunity must not be allowed, ie officials cannot illegally exercise their right to immunity.

The Charter of the Yugoslav Tribunal contains two different articles on war crimes (Article 2-3). Article 2 lists serious violations of the 1949 Geneva Conventions, and Article 3 lists specific actions under the heading "violations of the laws and customs of war". This distinction is related to the division of international humanitarian law into two parts: the protection of human rights in the event of an armed conflict ("Geneva law") and the limitation of methods and means of warfare ("The Hague law"). For example, Article 3 of the Tribunal's Statute states that the Tribunal has the power to prosecute those who violate the laws and customs of war. These violations include, but are not limited to [9]:

a) poisonous weapons or other designed to cause unnecessary suffering use of weapons;

b) intentional destruction of cities, settlements or villages or military necessity unjustified destruction;

c) pointless attacks on cities, villages, houses or buildings and or bombing;

d) institutions related to religion, education, art, historical and cultural monuments and art and seizing, destroying, or intentionally damaging scientific institutions;

e) looting of public or private property.

As can be seen from this article, the Yugoslav Tribunal prosecuted and punished each of the perpetrators of war crimes during its tenure. Article 2 of the Statute of the Yugoslav Tribunal refers to the authority of the Tribunal to prosecute those who have seriously violated or ordered the Geneva Convention of 12 August 1949.

1) premeditated murder;

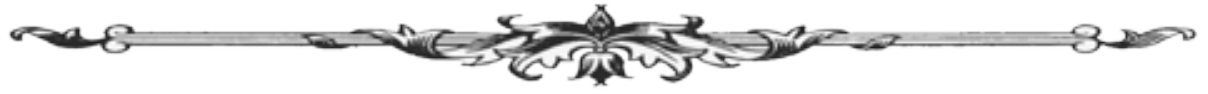


2) torture and inhuman treatment, including biological experiments;

3 ) intentionally inflicting severe pain or injury or damage to health; property;

4) illegal, arbitrary and large-scale destruction and misappropriation of non-military

5) to force a prisoner of war or a civilian to serve in the armed forces of the enemy;

6 ) intentional deprivation of a prisoner of war or a civilian of impartial and normal legal procedure;

7) illegal deportation, relocation or arrest of a civilian;

8) to take civilians hostage.

The tribunal has considered war crimes in Yugoslavia since 1991 in connection with violations of the Geneva Conventions, war and genocide. The requirements of Articles 2 and 3 also show that acts punishable by the Yugoslav Tribunal as war crimes have jurisdiction in violation of international humanitarian law and the requirements of the Geneva Conventions. As mentioned above, the Tribunal brought officials to justice for violating the requirements of these articles.

For the purposes of Article 2 of the Charter, the decision taken to determine the nature of the conflict in the former Yugoslavia must be analyzed. The Chamber of Appeals noted that the conflict in the former Yugoslavia had both domestic and international aspects, and that members of the Security Council were well aware of this [11, p. 39-43]. In other words, the Chamber of Appeals ruled that there were potentially different conflicts and did not automatically accept all of them as a single armed conflict of a purely international nature. According to the tribunal's charter, the territorial jurisdiction of the court belongs to the territory of the former Yugoslavia (excluding Slovenia), and the completion of the final process means the abolition of the court itself. Courts have the power to judge individuals, but not organizations or governments. The highest sentence a court can impose is life imprisonment. The court planned to complete all cases by 2009 and all appeals by 2010. However, since December 2014, appeals against Goran Hadzic, Ratko Mladic, Radovan Karadzic, Vojislav Seselj, Jadranko Prlic and a number of others have not been considered by the Tribunal. or, if this happens sooner, it has been extended until the work assigned to them is completed. The Security Council has decided to reappoint Serge Brammertzi as Prosecutor of the Tribunal.

It should be noted that the Yugoslav Tribunal is the first court to investigate war crimes after the Nuremberg Tribunal. It is known as an institution that has gained considerable prestige due to its research. At the time of its inception, many did not believe that it would operate in such a wide area and succeed. Due to its success, it is also considered a symbol of international law. The Yugoslav Tribunal was established in 1993, two years after the start of the Balkan conflict. At that time, in Western Europe, the helplessness of the peoples in the face of conflict and the impunity of specific individuals for the crimes committed during these conflicts were often the subject of discussion. Some politicians and diplomats said that the Yugoslav Tribunal was set up to show that at least something had been done, that it was created just to create an image. It was considered that the Tribunal could not impose economic sanctions, arms sanctions or military intervention. Proponents of the tribunal decided to speed up the process because they understood what steps they had taken and how important the tribunal would be for the countries.

The tribunal's first attorney general was Richard Goldstone, who is investigating atrocities against former black Africans in South Africa [12]. Principal and fearless, Richard Goldstone, despite pressure from a giant country like the United States, thwarted the December 1995 Dayton Accords (which provided for the pardon of officials who committed crimes) and charged 74 people with war crimes. Some advocated amnesty as a price for reconciliation, while Goldstone was adamant that pardon could not be a basis for those responsible for atrocities and inhumane acts to evade justice!

Seventy-six people were convicted of war crimes during Goldstone's time. Most of them were Bosnian Serbs who had committed crimes against Muslims in Bosnia. Goldstone also accused Croatians of Bosnian Muslims (for violence against both Serbs and Muslims). Dusko Tadic, who was hiding under the guise of a refugee in Germany, was arrested by German police, and in 1994

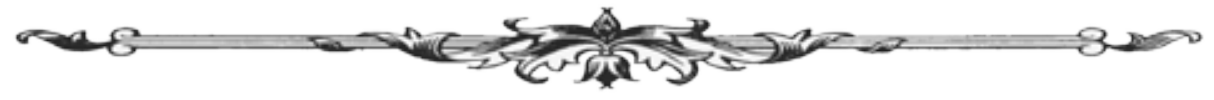


the first prisoner was taken from Germany by the Tribunal to be tried [11]. In 1995, the Tribunal charged two Bosnian Serb leaders, Radovan Karadzic [13] and Ratko Mladic [14], with organizing the ethnic cleansing and extermination of Croats and Muslims. So far, these two figures remain a symbol of impunity. In 1996, Tajikistan began considering the case. In April 1996, the Tribunal arrested a Croatian general, Tijomir Blaskic, a Croatian accused of ordering a major crime [15].

In late 1996, three and a half years after the tribunal was established, Louise Arbor, a Canadian law professor, was elected Attorney General. Such a case was new to her (she had previously considered civil and human rights cases, and chaired a commission to investigate the conditions of detention in women's prisons in Canada). Soon, however, he stressed the need to create a court that would actually work on war crimes, ensuring the proper outcome of his decisions [16, p. 52].

How can the truth be determined when the scale of the crime is so great? Several ethnic clashes in the Balkans in the 1990s resulted in mass killings. The effectiveness of the judiciary meant more than the establishment of historical events and the determination of fairness. It was necessary in real terms to solve the question: can there be real consequences for those who commit genocide, crimes against humanity, violate the rules of war, and how can the criminals in power be accounted for? Unlike the International Court of Justice in The Hague, the Yugoslav Tribunal is judging individuals. However, in practice this difference is not significant: individuals commit war crimes on behalf of the state, and their trial is decided by the Tribunal. Louise Arbor's most important task was to involve the states in cooperating with the Tribunal. And it was not so easy.

On May 22, 1999, the Yugoslav Tribunal issued its most important indictment against the head of state and a number of other high-ranking Serbian government officials on charges of war and crimes against humanity. In Kosovo, five people were charged and arrested on 22-27 May 1999, according to an announcement made by the Prosecutor General of the Tribunal [2]: Slobodan Milosevic, President of the Federal Republic of Germany Milan Milutinovic, President of Serbia, Deputy Prime Minister of the FRY Nikola Sainovic, Chief of General Staff of the Yugoslav Army Dragoljub Ojdanic and Minister of Internal Affairs of Serbia Vlajko Stojiljkovic. This indictment and the subsequent arrest warrant are noteworthy in several respects. The indictment is the first in the tribunal's history to charge a head of state during an ongoing armed conflict over serious violations of international humanitarian law. As of the date of the indictment, approximately 740,000 Kosovo Albanians, or one-third of the entire Kosovo Albanian population, had been expelled from Kosovo. They were more likely to be IDPs. An unknown number of Kosovo Albanians were killed in operations by FRY forces and the Republic of Serbia [17]. Specifically, five defendants are charged with the murder of more than 340 people attached to the indictment. Each of the accused is charged with persecution, murder and deportation, and violating the laws and customs of war. The prosecutor may expand the indictment, arguing that the indictment is exclusively based on crimes committed in Kosovo since early 1999, and that charges against other suspects in Kosovo could be added in addition to those in Croatia and Bosnia [16].

Of course, there were many who wanted to obstruct the objective investigation of the Yugoslav Tribunal. The perpetrators of the criminal cases investigated by the tribunal were not excluded, and the threat of arrest of certain individuals was against the interests of some. The tribunal's activities in Kosovo have also caused concern in some countries, however, the tribunal's activities in Kosovo were in full compliance with international law. The jurisdiction of the Tribunal for violations of international humanitarian law in Kosovo is completely legal under the mandate established by UN Security Council Resolution 827, of course, cannot be disputed. This has been repeatedly confirmed by UN Security Council resolutions on Kosovo, as well as by the Tribunal.

In general, the Yugoslav Tribunal has verdicts on war crimes. The tribunal went down in history as the first international tribunal to investigate war crimes related to sexual violence. The court proved to the world that the new international criminal justice system could end impunity for sexual crimes and that the perpetrators could be punished [17] The first lawsuit filed by the Yugoslav Tribunal over allegations of sexual violence was against Anto Furundžija [9]. The trial focused on the numerous rapes of a Bosnian Muslim woman during interrogations led by Furundžija, the commander of the Jokers, a special unit of the Croatian Defense Council. Not Furundžija himself, but

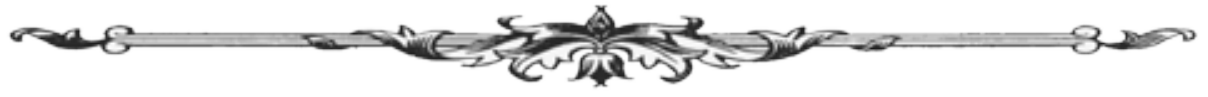


his subordinate, raped the woman in front of a laughing audience of other soldiers. Nevertheless, as a unit commander, Furundžija is convicted as a joint criminal and aide. The verdict was upheld on appeal and Furundžija was sentenced to 10 years in prison [18]. At the same time, the Judicial Chamber presented its legal considerations in the decision and expressed important views on the quality of aggression in the context of international crimes. The statement of aggression in the Tribunal's Charter is only one of the acts constituting crimes against humanity. The Court expanded the scope, stating that aggression could be prosecuted as a gross violation of the Geneva Conventions and a violation of the laws and customs of war. Judges also ruled that aggression could be used as an instrument of genocide. "The victim may constitute an act of genocide if the necessary elements are met and can therefore be prosecuted". As a follow-up to the Yugoslav Tribunal in 1998, the Rwandan Tribunal clarified the nature of aggression and the nature of war crimes in the Akayesu case [19].

The Judicial Chamber of the Yugoslav Tribunal has revealed how thousands of Muslims and Croats were detained in camps by Serbian forces after they seized the Prijedor region during the Yugoslav events. In a horrific incident in Omarska Camp, others, including one of the prisoners, Dusko Tadic, committed acts that constituted war crimes [20]. In May 1997, the Court found Tadic guilty of cruelty (violation of laws and customs of war) and inhumane acts (crimes against humanity) for his role in one incident or another [11]. Two years later, on appeal, Tadji was additionally convicted of a serious violation of the 1949 Geneva Conventions: inhuman treatment and intentional infliction of grievous bodily harm or serious injury. In the court ruling, the Chamber of Appeals said, "Duško Tadić, with his presence, helped and encouraged a group that was actively involved in the attack. Of particular concern here is the abuse and humiliation of victims and other prisoners". In January 2000, Tadiç was sentenced to 20 years in prison.

Conclusions. The verdict of the Yugoslav Tribunal in Ivica Rajic also proved a number of elements that constitute war crimes [24, p. 433]. Ivica Rajic was in charge of several units of the Croatian Defense Council and was the commander of the 2nd Operational Group, the Croatian Defense Council, in the operational zone in Central Bosnia. On October 23, 1993, Ivica Rajic was ordered to arrest several official Bosnian Croats in the central Bosnian city of Vares. On the same day, Croatian Defense Council troops under Rajic's command searched the city and arrested 250 Muslim men. During the arrests, Defense Council soldiers entered homes, tortured, insulted, and tortured people. At the same time, the detainees were taken to the worst school buildings in the city of Vares and tortured. Then, on October 23, 1993, units under Rajic's command stormed the village of Stupni-Do, took control of the village, and looted it as well as the town of Vares, and raped Muslim women. At least 37 women and men were killed here. As a result of the attack, the village was completely destroyed. In order to cover up his crimes, on December 27, 1993, Ivica Rajic was renamed Victor Andric by the Defense Council and appointed commander with a legal document. It is alleged that the perpetrators were not named Rajic, but Victor. However, Ivica Rajic was prosecuted under Article $\S 7 \S 1$ and 3 of the Charter of the Yugoslav Tribunal. At the same time, he committed five serious violations of the 1949 Geneva Conventions, including murder, torture, rape, violence against civilians, illegal confiscation of property, and numerous acts of vandalism without military necessity. To this end, the Tribunal prosecuted him for both crimes against humanity and war crimes. The tribunal prosecuted him and on October 26, 2005, on four grounds:

1) Committing crime of murder under Article 2 of the Geneva Conventions;

2) The occurrence of serious violations, inhumane acts and rape prohibited by Article 2 of the Charter of the Yugoslav Tribunal and at the same time by the Geneva Conventions;

3) Illegal confiscation of property in accordance with Article 2 of the Charter of the Tribunal;

4) Large-scale destruction of towns and villages without military necessity in accordance with Article 2 of the Statute of the Tribunal and the Geneva Conventions.

Finally, on May 8, 2006, Rajic was sentenced to 12 years in prison.

These facts also show that the Yugoslav Tribunal convicted and punished those accused of war crimes, regardless of their status.

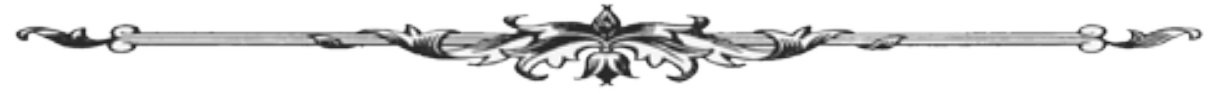




\section{References:}

1. Hüseynov, L.H. Beynəlxalq hüquq. Dərslik Bakı: Qanun nəşriyyatı, 2012, 368 səh.

2. Oliyev, Ә.İ. Azərbaycan beynəlxalq cinayətlər hədəfində: hüquqi təhlil. Nurlar, Bak1, 2018, $178 \mathrm{~s}$.

3. Лукашук И.И. Международное право. Москва : Wolters Kluwer, 2005.

4. Bass, Gary Jonathan, Stay the Hand of Vengeance: The Politics of War Crimes Tribunals, Princeton University Press-, 2002500 pg.

5. Brief to Support the Motion on the Jurisdiction of the Tribunal), Section 3 (Defence Trial Brief), 23 June 1995.

6. Brownlie, International law and the Use of Force by States, Oxford University Press, 1963 , p. 159.

7. Dieter, Fleck (ed.), The Handbook of Humanitarian Law in Armed Conflict. Oxford: Oxford University Press, 1995. DOI: 10.1093/law/9780199658800.001.0001 Pp. xvi, 584 p.

8. The Practice of the International Criminal Tribunals for the fomer Yugoslavia and Rwanda /Cohn R.W.D. Cones, Transnational Publishers, Inc. Ardsley, New-York, 2000, https:// www.nyulawglobal.org/globalex/International_Criminal_Courts.html [accessed 6 May 2021]

9. UN Security Council, Statute of the International Criminal Tribunal for the Former Yugoslavia (as amended on 17 May 2002), 25 May 1993, available at: https://www.refworld.org/ docid/3dda28414.html [accessed 6 May 2021]

10. Prosecutor, V. Anto Furund `ija, Case No. IT-95-17/1-T, Judgement, 10 Dec. 1998 ("the Judgement")

11. Protocol Additional to the Geneva Conventions of August 12, 1949 and relating to the Protection of Victims of International. Armed Conflicts (Protocol I), 12 June 8, 1977 at http:// www.unhchr.ch/html/menu3/b/93.htm [accessed October 8, 2002]

12. Press Release, The Hague, 27 May 1999, JJL/PIU/403-E

13. Akayesu Judgement, supra note 77, at 17. Rwanda is divided into 11 prefectures, which are further subdivided into communes (similar to United States' cities divided into districts). https:// core.ac.uk/download/pdf/232967118.pdf [accessed 6 May 2021]

14. International Criminal Justice at the Yugoslav Tribunal: A Judge's Recollection, Author by Mohamed Shahabuddeen, Oxford 2012.

15. Louise Arbour, War Crimes and the Culture of Peace, University of Toronto Press, Scholarly Publishing Division, 2002 M12 15 - 80 pg.

16. Gerhard Werle, Principles of International Criminal Law, T.M.C. Asser Press (2nd edition 2009) p. 476-477, para. 1312.

17. In 1946 the General Assembly of the UN adopted resolution 95 (I) in which it affirmed the "principles of international law recognized by the Charter of the Nuremberg Tribunal and the judgment of the Tribunal". See, Antonio Cassese, International Criminal Law, Oxford University Press, 2003, p. 111.

18. W. J. Fenrick, 'İnternational Humanitarian Law and Criminal Trials',Transnational Law \& Contemporary Problems, 7/1 (1997), 26.

19. War Crimes and the Culture of Peace, Louise Arbour, University of Toronto Press, Scholarly Publishing Division, 2002 M12.

20. Warrants of Arrest and Orders for Surrender against all the accused, Case No. IT-37-I, of 24 May 1999.

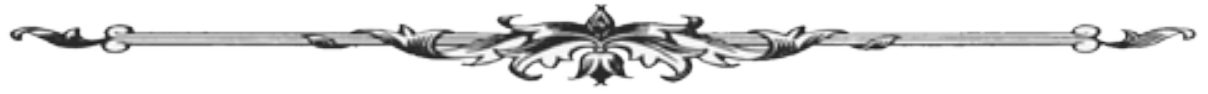

